\title{
PERMASALAHAN PEMBELAJARAN IPA SMP/MTS DI KABUPATEN SUMENEP TAHUN AJARAN 2010-2011
}

\author{
Habibi, Anik Anekawati, Lutfiana F.A. \\ Prodi Pendidikan IPA, Universitas Wiraraja Sumenep
}

\begin{abstract}
ABSTRAK
Tujuan penelitian ini adalah untuk mengeksplorasi dan menggambarkan bagaimana permasalahan pembelajaran IPA SMP/MTs di kabupaten Sumenep.Selain itu juga untuk menggambarkan disparitas permasalahan yang terjadi.Pengambilan data penelitian dilaksanakan pada beberapa SMP/MTs di kabupaten Sumenep yang dipilih secara acak purposif dengan menggunaan metode angket (untuk siswa) dan diskusi kelompok terfokus (untuk guru dan kepala sekolah).Data dianalisis secara deskriptif kualitatif dengan menggunakan teknik analisis konten yang terdiri atas tiga tahap utama yaitu katagorisasi (open coding), membuat relasi antar katagori (axial coding) dan teoretisasi (selective coding).Temuan yang didapatkan dalam penelitian ini yaitu adanya enam katagori permasalahan utama dalam pembelajaran IPA SMP/MTs di Kabupaten Sumenep, antara lain: kualitas belajar siswa, latar belakang budaya dan orang tua, komunikasi sekolah-orang tua, kondisi guru, sarana-prasarana pendukung pembelajaran dan kurikulum-kebijakan. Disparitas permasalahan yang terjadi terutama pada tiga kelompok sekolah yang cenderung semakin meningkat kompleksitasnya yaitu sekolah favorit, sekolah nonfavorit dan sekolah dalam pesantren.
\end{abstract}

Kata Kunci: Permasalahan Pembelajaran IPA, SMP/MTs, Disparitas

\section{PENDAHULUAN}

UU Sisdiknas mengamanatkan bahwa pemerintah daerah berkewajiban untuk mengembangkan satuan pendidikan pada jenjang pendidikan dasar dan menengah menjadi berbasis keunggulan lokal, yang mengacu pada penyesuaian program dan kegiatan pendidikan yang menunjang pengembangan kompetensi yang berbasis potensi sosial, ekonomi, dan/ budaya unggulan daerah. Dengan demikian, satuan pendidikan dirancang sebagai motor penggerak pembangunan daerah (Departemen Pend. Nasional, 2009).

Pendidikan sebagai pusat pembudayaan dan pembangunan masyarakat merupakan perwujudan dari konsep pendidikan sebagai investasi modal manusia (human capitalinvestment). Kebijakan menjadikan pendidikan sebagai instrumen pemberdayaan masyarakat mengacu pada penyelenggaraan satuan pendidikan berbasis keunggulan lokal.

Dalam hal prestasi siswa-siswa Indonesia di ajang internasional, pada tahun 2008 telah diperoleh 117 medali emas. Capaian ini jauh di atas target nasional sebesar 20 medali emas. Distribusi medali emas tersebut pada jenjang pendidikan dasar adalah 52 medali, pada jenjang pendidikan menengah 36 medali dan pada jenjang pendidikan tinggi 29 medali. Prestasi ini menunjukkan bahwa wakilwakil peserta didik Indonesia mampu bersaing dengan peserta dari negara-negara lain.

Walaupun sebagian siswa telah berhasil mengukir prestasi di tingkat internasional dengan memenangkan medali emas dalam berbagai ajang olimpiade internasional, prestasi siswa Indonesia secara umum masih memprihatinkan. Salah satu masalah pendidikan nasional adalah mutu pendidikan. Walaupun dalam berbagai olimpiade internasional peserta dari Indonesia telah berhasil mengukir prestasi dengan meraih medali emas, perak, dan perunggu sebagai salah satu tanda mutu yang tinggi, secara global, mutu pendidikan Indonesia masih termasuk rendah. Pada level regional, kualitas pendidikan Indonesiarelatif lebih rendah bila dibandingkan dengan pencapaian negaranegara ASEAN lainnya seperti Thailand, Malaysia, dan Filipina. Hal ini dapat dilihat dari hasil studi yang diselenggarakan oleh IEA (International Organization for Evaluation of Educational Achievement) 
yang juga diikuti oleh Indonesia bersama beberapa negara lainnya dalam TIMSS (Trends inInternational Mathematic and Science Study). Study PISA (Programme forInternational Student Assesment) yang diselenggarakan oleh OECD (Organizationfor Economic Cooperation and Development) pada tahun 2006 menunjukkan bahwa skor Tes PISA pada aspek literasi, numerasi, dan sains masih lebih rendah dari skor negara-negara nonOECD dan negara-negara OECD. Pada kondisi tersebut Indonesia menduduki urutan kelima dari bawah dari 54 negara. Berdasarkan parameter EDI (Education Development Index) Indonesia menduduki peringkat 71 (medium EDI). Data tersebut di atas menunjukkan bahwa dilihat dari segi mutu, Indonesia masih tergolong negara dengan mutu pendidikan yang belum dapat dibanggakan. Sementara itu, untuk bidang IPA, perkembangan nilai PISA cenderung stagnan. Kondisi ini mengkhawatirkan dan berkebalikan dengan banyak medali yang diperoleh Indonesia dalam berbagai kompetisi di bidang IPA (Departemen Pendidikan Nasional, 2009).

$$
\text { Ilmu Pengetahuan Alam (IPA) }
$$
berkaitan dengan cara mencari tahu tentang alam secara sistematis, sehingga IPA bukan hanya penguasaan kumpulan pengetahuan yang berupa fakta-fakta, konsep-konsep, atau prinsip-prinsip saja tetapi juga merupakan suatu proses penemuan. Pendidikan IPA diharapkan dapat menjadi wahana bagi peserta didik untuk mempelajari diri sendiri dan alam sekitar, serta prospek pengembangan lebih lanjut dalam menerapkannya di dalam kehidupan sehari-hari. Proses pembelajarannya menekankan pada pemberian pengalaman langsung untuk mengembangkan kompetensi agar menjelajahi dan memahami alam sekitar secara ilmiah. Pendidikan IPA diarahkan untuk inkuiri dan berbuat sehingga dapat membantu peserta didik untuk memperoleh pemahaman yang lebih mendalam tentang alam sekitar (Permendiknas no. 22 tahun 2006).
Kabupaten Sumenep merupakan salah satu daerah dengan struktur budaya lokal yang bercorak kehidupan pesisir. Profesi utama masyarakat Sumenep adalah petani dan nelayan. Dalam bidang pendidikan, Sumenep merupakan miniatur dari kondisi pendidikan Indonesia yang masih memprihatinkan, sebagai contoh di beberapa kecamatan (Ganding dan Pragaan) kualifikasi kelayakan mengajar guru masih berada berada di bawah $40 \%$ (Dinas Pendidikan Sumenep, 2008).

Menyambut pembenahan dan pembangunan Madura pasca jembatan Suramadu, sektor pendidikan seharusnya menjadi prioritas dalam meningkatkan kualitas sumber daya manusia madura di masa depan. Adapun ujung tombak dari Pengembangan kurikulum yang realistis bagi tujuan tersebut adalah pada bidang sains dan teknologi. Berdasarkan kurikulum KTSP, orientasi kurikulum IPA kita tidak hanya mengarahkan anak didik menjadi kreatif dan berdaya saing, melainkan juga beriman, bermoral, dan mencintai kultur budaya masyarakatnya.

Sumenep memiliki potensi lokal yang dapat manjadi motor penggerak pengembangan kurikulum pembelajaran IPA, diantaranya potensi kekayaan sumber daya alam yang belum tergali dan juga kultur masyarakat lokal yang pada dasarnya memberikan penghargaan yang lebih terhadap dunia pendidikan. Namun potensi belum akan menghasilkan upaya pengembangan yang optimal tanpa suatu pemetaan permasalahan secara cermat dan sistematis. Pemetaan permasalahan dalam pembelajaran IPA memiliki nilai penting untuk mengarahkan pengembangan kurikulum IPA yang tepat bagi pemberdayaan masyarakat pesisir di Madura dalam menyongsong era global.

\section{METODE PENELITIAN}

Jenis penelitian ini adalah deskriptif kualitatif. Tujuan penggunaan jenis penelitian ini adalah untuk memberikan kejelasan secara deskriptif bagaimana kondisi permasalahan yang terjadi pada 
pelaksanaan pembelajaran IPA tingkat SMP/MTs di Kabupaten Sumenep. Subyek dalam penelitian ini meliputi pihak-pihak utama yang terlibat dalam proses pembelajaran IPA yaitu siswa, guru, dan kepala sekolah di beberapa sekolah di Kabupaten Sumenep. Subyek-subyek penelitian dipilih secara acak porposif dan kemudian dilakukan pengambilan data melalui angket dan diskusi kelompok terfokus (focus group discussion/FGD).Penelitian ini dilakukan pada bulan Februari 2011. Adapun tempat pengambilan data penelitian adalah pada beberapa sekolah SMP/MTs di kabupaten Sumenep yang dipilih secara acak purposif.

\section{HASIL DAN PEMBAHASAN 3.1 Gambaran Permasalahan Pembelajaran IPA SMP/MTs di Kabupaten Sumenep}

Pembelajaran merupakan sebuah proses yang bersifat sistemik, artinya terdiri dari unsur-unsur yang saling berhubungan yang tidak terpisahkan. Secara kompleks masing-masing bagian dalam sistem yang melingkupi berjalannya proses pembelajaran saling berkaitan dan mempengaruhi. Oleh karena itu untuk menulusuri permasalahan yang terjadi pada suatu proses pembelajaran secara mendalam, maka harus dilakukan penelusuran permasalahan pada setiap bagian yang saling berkaitan tersebut.

Dalam penelitian ini unsur-unsur dalam sistem pembelajaran IPA yang dikaji dan ditelusuri adalah berdasarkan pada konsep yang dimiliki oleh Jerold F. Kemp mengenai pengembangan suatu pembelajaran. Adapun unsur-unsur yang menyusun suatu sistem pembelajaran yang dieksplorasi dalam penelitian ini antara lain adalah: tujuan pembelajaran, kondisi siswa, kondisi guru, kondisi sekolah, materi pembelajaran, metode pembelajaran, sistem penilaian dan media pembelajaran. Unsurunsur lain yang muncul dalam penelitian dianalisis tetap dalam sebuah kesatuan sistem yang saling berkaitan dengan unsurunsur lainnya.

Pusat permasalahan yang menjadi titik awal dari eksplorasi masalah- masalah dalam pembelajaran IPA SMP/MTs di Kabupaten Sumenep ini adalah motivasi dan kualitas belajar siswa. Perlu diketahui sebelumnya bahwa kata kualitas belajar dalam bahasa para guru dalam penelitian ini sebenarnya adalah daya serap siswa. Istilah daya serap ini nampaknya menggambarkan bagaimana paradigma para guru yang masih cenderung berorientasi pada transfer materi (pengetahuan), dimana siswa menjadi hanya obyek saja. Istilah kualitas belajar dipilih berdasarkan paradigma yang dimiliki peneliti, yaitu siswa sebagai aktor aktif dalam proses belajar, diharapkan dapat menunjukkan bagaimana substansi permasalahan yang terjadi.

Berdasarkan hasil penelitian, baik dari data angket ataupun diskusi fokus grup, didapatkan suatu fakta bahwa pandangan awal siswa terhadap pembelajaran IPA adalah menyenangkan/menarik. Namun hal tersebut ternyata tidak berlanjut pada kualitas belajar yang baik, terutama pada sekolah-sekolah non favorit ataupun sekolah dalam pesantren.

Berawal dari titik awal permasalahan inilah kemudian unsur-unsur lain dari sistem pembelajaran dieksplorasi sehingga dapat menghasilkan suatu deskripsi permasalahan pembelajaran IPA SMP/MTs di Kabupaten Sumenep secara lebih komphrehensif. Dalam penelitian ini diperoleh lima katagori utama yang melingkupi permasalahan utama mengenai kualitas belajar siswa. Kelima katagori tersebut adalah (1) latar belakang budaya dan keluarga, (2) komunikasi sekolah-orang tua, (3) kondisi guru, (4) sarana-prasarana pendukung pembelajaran dan (5) kurikulum dan kebijakan. Secara sederhana kelima katagori ini berpengaruh terhadap katagori kualitas belajar siswa seperti pada Gambar 4.3 yang tersaji berikut ini: 


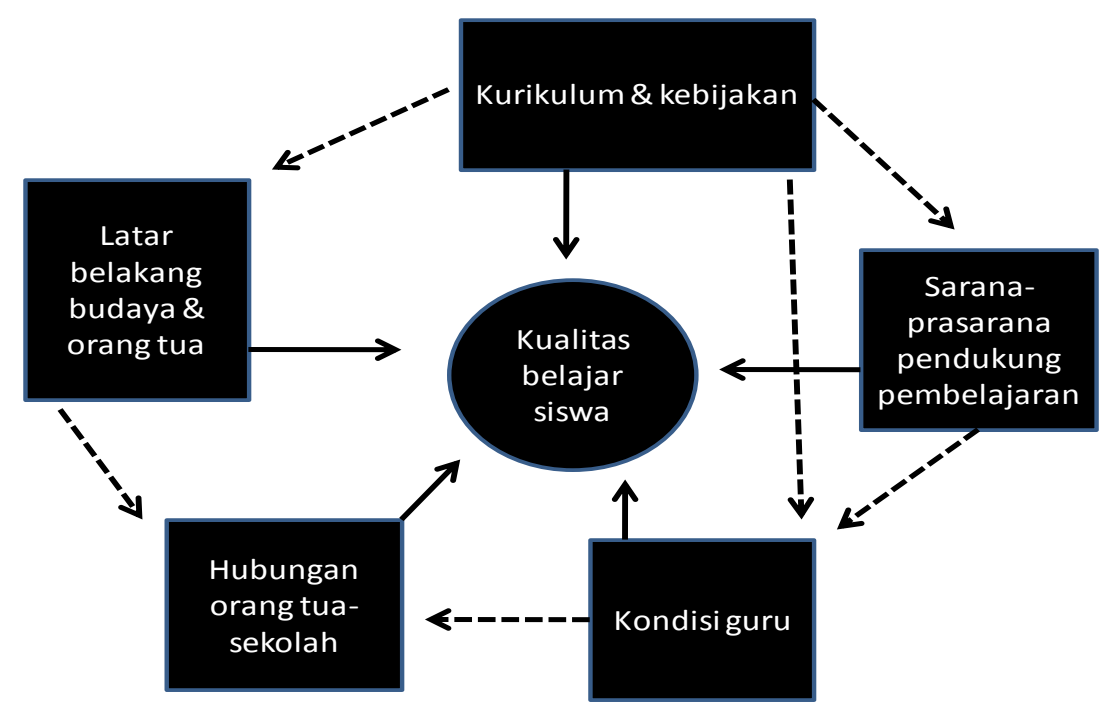

Gambar 4.3 Permasalahan Pembelajaran IPA SMP/MTs di Kabupaten Sumenep Tahun Ajaran 2010-2011

\section{a. Latar Belakang Budaya dan Orang Tua}

Salah satu penyebab utama dari kondisi kualitas belajar siswa adalah latar belakang budaya dan orang tua siswa. Budaya merupakan way of life dari suatu masyarakat, lebih lengkapnya Albrow (1999) menyebutkan budaya sebagai way of thinking, acting and feeling which are transmitted through learning. Dalam makna tersebut, cara hidup masyarakat dipengaruhi oleh cara pandangnya mengenai kehidupan, termasuk juga institusi sekolah secara umum dan dalam penelitian ini khususnya adalah pembelajaran IPA.

Dalam penelitian ini didapatkan gambaran paradigma masyarakat (orang tua) terhadap peran sekolah dalam hal pendidikan anak. Pandangan umum yang banyak didapatkan oleh para guru dari orang tua siswa adalah pandangan bahwa sekolah adalah satu-satunya pihak yang bertanggung jawab penuh atas proses pendidikan anak. Hal ini berakibat pada diabaikannya aktivitas belajar anak di rumah.Kondisi ini terutama terjadi pada sekolah-sekolah non favorit atau sekolahsekolah dalam pesantren.

Salah satu faktor yang menjadi penyebab paradigma yang salah ini adalah tingkat pendidikan. Sekolah-sekolah nonfavorit terutama di daerah pedalaman Sumenep, dimana latar belakang profesi masyaraktnya adalah petani atau nelayan dengan tingkat pendidikan yang rendah.

Tingkat pendidikan dan proses belajar mempengaruhi world view (pandangan dunia) seseorang. Orientasi hidup menciptakan nilai-nilai dan hal-hal yang bermakna atau sebaliknya. Masyarakat yang berpendidikan rendah tentunya memiliki anggapan bahwa pendidikan hanyalah bersifat formalitas, mereka tidak dapat melihat aspek substansial dan bermakna dari proses belajar anak. Oleh karenanya dapat dimaklumi jika orang tua akan merasa lebih baik atau lebih bangga untuk membelikan anak-anaknya sepeda motor atau HP daripada memenuhi kebutuhan anaknya akan buku-buku pelajaran di sekolah.

Proses kehidupan anak di rumah menjadi hanya sekedar rutinitas yang tidak terevaluasi secara sadar oleh para orang tuanya. Aktivitas rutin mulai dari berangkat sekolah, pulang, bermain, mengaji dan tidur menjadi sebuah siklus harian yang tidak terevaluasi. Bagaimana perkembangan belajar anak, permasalahan apa yang dihadapinya, bagaimana dengan prestasi dan motivasi mereka, hal-hal tersebut 
jarang sekali mendapat perhatian dari orang tua.

Faktor perkembangan teknologi informasi menjadi pendorong semakin jauhnya anak-anak dari perhatian dan kontrol orang tua.Informasi yang sedemikian cepat membuat pola kebiasaan yang menghambat belajar, terutama menikmati berbagai macam hiburan baik di televisi maupun internet, semakin meningkat.Bahkan tren negatif seperti pornografi dari razia yang seringkali dilakukan sekolah terhadap HP para siswa menjadi gambaran bahwa perubahan budaya menjadi permasalahan yang cukup serius dalam pembelajaran.

Budaya masyarakat seperti ini menyebabkan masyarakat menjadi jauh dari sekolah.Akibatnya komunikasi antara sekolah dan orang tua menjadi sulit untuk diwujudkan.

\section{b. Komunikasi Sekolah-Orang Tua}

Komunikasi antara sekolah dan orang tua merupakan media yang dapat menjaga keberlangsungan proses pengontrolan dan pengarahan untuk para siswa dalam belajar. Transfer informasi dan pembentukan pengalaman belajar siswa di sekolah dilakukan oleh guru dengan suatu sistem komunikasi yang bersifat akademik. Demikian pula pengarahan dan pendidikan siswa di rumah dilakukan oleh orang tua melalui suatu proses komunikasi yang lebih bersifat interpersonal. Sesuai dengan prinsip pendidikan sebagai sebuah sistem, seharusnya kedua proses tersebut daling berhubungan secara aktif dan terpadu. Keterpaduan fungsional antar guru dan orang tua dapat berlangsung walaupun tidak diikuti oleh keterpaduan struktural, hal ini dapat diwujudkan melalui suatu bentuk komunikasi spesifik berlandaskan tujuantujuan kependidikan secara utuh kepada siswa.

Dalam penelitian ini didapatkan data bahwa komunikasi guru dan orang tua ternyata menjadi permasalahan yang mempengaruhi menurunnya kualitas pembelajaran siswa di kabupaten Sumenep, khususnya dalam pembelajaran IPA. Permasalahan komunikasi ini menyebabkan proses belajar anak terputus hanya di sekolah, terutama pada sekolah-sekolah nonfavorit. Penyebabnya terutama seperti yang telah disebutkan pada katagori sebelumnya yaitu latar belakang budaya yang sangat dipengaruhi oleh tingkat pendidikan orang tua. Paradigma bahwasannya ketika anak telah bersekolah maka sepenuhnya pendidikan merupakan tanggung jawab sekolah membuat orang tua seperti melepaskan pengawasannya terhadap anak dalam hal belajar.

Sekolah sebenarnya dapat melakukan upaya aktif untuk membangun komunikasi dengan orang tua, namun tentunya dengan energi dan waktu yang cukup banyak. Apalagi bagi institusi dalam pesantren yang memiliki siswa berasal dari daerah-daerah pelosok (jauh). Upaya tersebut tampaknya sulit dilakukan oleh sekolah, bagi mereka permasalahan-permasalahan internal sekolah sendiri masih lebih perlu untuk diperhatikan. Salah satunya adalah kondisi guru sebagai pelaksana pembelajaran.

\section{c. Kondisi Guru}

Guru memegang peranan penting dalam mewujudkan pembelajaran bagi siswa. Meskipun prinsip pendidikan kita saat ini telah lebih bersifat student centered, namun gurulah yang merancang pembelajaran agar situasi tersebut dapat tercipta. Sebagai aktor utama dalam sistem pendidikan kita, Undang-undang (UU no. 14 tahun 2005) membuat sebuah standar kompetensi yang harus dipenuhi oleh para guru dalam menjalankan kewajibannya. Empat standar kompetensi guru tersebut adalah kompetensi pedagogik, kompetensi kepribadian, kompetensi sosial dan kompetensi profesional.

Dalam penelitian ini gambaran permasalahan terkait kondisi guru dihasilkan secara kualitatif dan menghubungkannya dengan permasalahanpermasalahan lain yang melingkupi kualitas proses pembelajaran IPA. Untuk mengetahui bagaimana tingkat pemenuhan 
para guru IPA SMP/MTs di Sumenep akan empat kompetensi standar tersebut diperlukan suatu penelitian komprehensif dan terpadu lebih lanjut.

Permasalahan pertama yang muncul mengenai guru adalah mengenai metode pembelajaran IPA yang diterapkan, dimana metode ceramah atau metode-metode lain yang masih bersifat tranfer langsung seperti presentasi dengan media proyektor, menggambar, dan pemberian latihan, masih medominasi. Hal ini agak berlawanan dengan karakter pembelajaran IPA yang dasarnya adalah proses belajar aktif secara kontekstual untuk memahami dan menemukan prinsip-prinsip kerja alam. Alasan utama yang dikemukakan oleh para guru adalah kondisi siswa serta daya dukung sarana (terutama laboratorium) yang tidak memadai.

Permasalahan berikutnya adalah mengenai pelaksanaan RPP yang disusun. Secara administratif para guru telah memenuhi tugasnya untuk merancang dan merencanakan proses pembelajaran dalam draft RPP. Namun ini tidak berlanjut secara fungsional di kelas. RPP menjadi hanya sekedar pelindung dari tuntutan administratif yang diberikan oleh kepala sekolah. Alasan utama yang diberikan adalah karena lemahnya supervisi kelas dari kepala sekolah, serta RPP yang harus telah diselesaikan secara keseluruhan di awal tahun sehingga membuat mereka sulit beradaptasi dengan berbagai perubahan insidental.

Permasalahan terakhir terkait kondisi guru adalah adanya sifat malas dalam diri guru untuk mengembangkan pembelajarannya. Hal tersebut terutama terjadi para guru-guru yang telah senior sehingga merasa benar-benar menguasai bidangnya sehingga merasa malas untuk belajar dan melakukan perubahanperubahan baru.

Ketiga masalah tersebut sebenarnya saling terkait dalam suatu rantai sebab akibat yang logis. Meskipun data yang didapatkan menunjukkan kekhususan yang memisahkan permasalahan-permasalahan tersebut, namun secara analitis kita dapat mengetahui hubungan diantara ketiganya. RPP dan metode mengajar adalah dua hal yang sangat berkaitan. Tanpa perencanaan yang baik maka metode yang digunakan tentunya akan bersifat monoton dan tidak sistematis. Mengapa ini terjadi? Bukan hanya kontrol atau supervisi kepala sekolah saja yang menjadi penyebabnya, akan tetapi lebih utama dari faktor guru sendiri yang mengakui terdapatnya kemalasan untuk mengembangkan pembelajaran.

Apa yang menyebabkan karakter malas pada diri guru dalam mengembangkan pembelajarannya secara serius? Jika kita kaitkan dengan berbagai permasalahan lain yang muncul, maka kita akan mendapatkan suatu jaring-jaring permasalahan yang saling berkait. Faktorfaktor seperti budaya materialistik, KKN, inkonsistensi kebijakan, penilaian yang berorientasi kuantitas (dalam bahasa mereka, "seperti melakukan pembodohan") dan juga minimnya sarana merupakan tumpukan permasalahan yang membuat guru seperti menunjukkan sikap 'menyerah' terhadap keadaan.

\section{d. Sarana dan Prasarana Pendukung Pembelajaran IPA}

Pada permasalahan mengenai metode yang digunakan guru untuk mengajar diperoleh suatu gambaran bahwa sebagian besar guru masih menggunakan metodemetode transfer informasi langsung dalam mengajar IPA. Hal ini juga diperkuat oleh hasil survey yang dilakukan terhadap siswa. Alasan utama yang diberikan para guru menyangkut miskinnya metode pembelajaran yang digunakan ini adalah karena daya dukung sarana dan prasarana yang tidak memadai.

Sarana dan prasarana utama dalam mendukung pembelajaran IPA dalam hal ini adalah laboratorium dan perpustakaan. Di dalam laboratorium para siswa akan dihadapkan pada pengalaman-pengalaman dimana mereka akan berbenturan dengan konsep-konsep dalam IPA secara nyata. Secara ekonomi pemenuhan sarana dan 
prasarana laboratorium, baik dalam penyediaan awal ataupun pemeliharaannya, masih menjadi masalah yang tidak mampu dipecahkan oleh sekolah-sekolah terutama di daerah terpencil (non favorit). Sedangkan perpustakaan yang ada umumnya berisi buku-buku ajar. Buku-buku pendukung dan pengayaan yang standar (sesuai dengan Permendiknas No. 24 Tahun2007 tentang standar sarana dan prasarana) juga tidak mampu dipenuhi.

Kesulitan sekolah untuk memenuhi standar sarana dan prasarana pendukung pembelajaran terutama untuk IPA adalah karena faktor pendanaan. Dana operasional utama di SMP/MTs adalah berasal dari dana BOS yang alokasi penggunaannya telah diatur oleh pemerintah. Dari sumber ini ternyata tidak ada alokasi dana untuk penyediaan prasarana dan sarana laboratorium yang sesuai dengan standar pendidikan IPA. Untuk mencari sumber dana yang lain, kesulitan sekolah terutama dari paradigma masyarakat yang dibentuk secara politis bahwa sekolah (tingkat dasar dan menengah pertama) adalah gratis, yang artinya sama sekali sekolah dilarang untuk mengambil dana dari masyarakat sebesar apapun.

Dalam pemenuhan sarana dan prasarana pendukung pembelajaran sebenarnya setiap tahunnya pemerintah selalu memberi kucuran dana (lebih tepatnya alat-alat secara langsung) khusus kepada sekolah-sekolah yang mengajukan permohonan. Namun bantuan tersebut tidak dapat diberikan kepada banyak sekolah dikarenakan faktor dana yang dimiliki oleh pemerintah sendiri, sehingga terjadi sebuah antrean yang sangat panjang. Akibatnya adalah hingga saat ini lebih banyak sekolah yang tidak memiliki fasilitas laboratorium dan perpustakaan standar untuk pembelajaran IPA. Bahkan dalam penelitian ini ditemukan sekolah dengan yang memiliki status SSN (Sekolah Standar Nasional) namun tidak memiliki laboratorium. Dalam kasus tersebut, ruangan yang sebelumnya dialokasikan untuk laboratorium ternyata terpaksa digunakan untuk kelas.

\section{e. Kurikulum dan Kebijakan}

Katagori terakhir dalam permasalahan pembelajaran IPA SMP/MTs di Kabupaten Sumenep hasil temuan dalam penelitian ini adalah mengenai kurikulum dan kebijakan. Aspek permasalahan kurikulum yang ditemukan terutama mengenai penilaian dalam pendidikan yang semakin cenderung berorientasi pada kuantitas. Makna kuantitas disini adalah nilai-nilai yang ditunjukkan oleh angka di raport, ijazah ataupun angka-angka yang menunjukkan jumlah siswa yang naik kelas dan lulus. Perhatian utama sekolah ataupun pemerintah masih pada upaya untuk mempertahankan atau meningkatkan angkaangka kuantitatif ini. Adapun kualitas sebenarnya dari proses pembelajaran belum benar-benar menjadi acuan utama dari sistem penilaian dan kurikulum pada umumnya. Puncak dari permasalahan ini terjadi pada Ujian Nasional, dimana kualitas pendidikan benar-benar kurang diperhatikan (terutama melalui cara-cara tidak benar yang dilakukan oleh tim sukses sekolah) dengan berbagai alasan seperti tekanan dari atas, nama baik sekolah, dan juga nasib siswa.

Permasalahan berikutnya dalam katagori ini adalah intervensi kepentingan politik dan inkonsistensi kebijakan. Makna kata inkonsisten dalam hal ini mengacu pada ketidaktetapan penerapan suatu kebijakan di lapangan karena kepentingan pihak-pihak tertentu. Hal ini berhubungan dengan intervensi politik, karena kepentingan-kepentingan yang memunculkan inkonsistensi kebijakan dapat saja berasal dari kepentingan politik pihakpihak tertentu. Konsistensi kebijakan merupakan gambaran bagaimana penegakan aturan-aturan dalam hal ini adalah aturan-aturan dalam dunia pendidikan. Contoh inkonsistensi yang ditemukan dalam penelitian ini adalah mengenai penentuan jumlah siswa baru pada tiap kelas. Berdasarkan Standar 
Nasional Pendidikan ditetapkan bahwa jumlah maksimal siswa pada tiap rombongan adalah 32 siswa. Namun pada pelaksanaan di lapangan terjadi perubahan, terutama pada sekolah-sekolah favorit yang memperbesar jumlah penerimaan siswanya pada tiap rombongan. Hal ini membuat sekolah nonfavorit mengeluhkan adanya kesulitan dalam memperoleh siswa, terutama siswa dengan kualitas belajar yang baik.

Intervensi politik, yang mempengaruhi kualitas pembelajaran yang ditemukan dalam penelitian ini terkait dengan kenaikan kelas atau kelulusan sekolah. Sebuah pernyataan tidak tertulis yang beredar di kalangan guru dan siswa yang mengungkapkan bahwa "belajar atau tidak, pasti naik kelas atau lulus," memiliki keterkaitan dengan kepentingan politik para pemegang kebijakan yang lebih memilih aman dengan melihat keberhasilan semu pendidikan. Meskipun ini bukan satusatunya faktor yang menjadi penyebabnya, namun temuan penelitian menunjukkan bahwa permsalahan tersebut banyak berasal dari pihak atas (pemerintah).

\subsection{Disparitas Pembelajaran IPA SMP/MTs di Kabupaten Sumenep}

Berdasarkan temuan penelitian mengenai permasalahan pembelajaran IPA SMP/MTs di Kabupaten Sumenep diketahui bahwa permasalahanpermasalahan tersebut saling terkait sehingga membentuk suatu jaring permasalahan yang telah dibahas sebelumnya. Selain saling berkait, permasalahan-permasalahan tersebut memiliki tingkat perbedaan pada beberapa kondisi sekolah. Perbedaan ini membentuk suatu kesenjangan (disparitas) yang membagi jenis sekolah menjadi tiga golongan yaitu sekolah favorit, sekolah nonfavorit dan sekolah dalam pesantren.
Secara kualitatif disparitas permasalahan yang terjadi pada ketiga golongan sekolah tersebut dapat digambarkan seperti yang tersaji pada Tabel 4.1. Disparitas permasalahan terjadi pada empat katagori permasalahan yaitu: kualitas belajar siswa, latar belakang budaya dan orang tua, kondisi guru, serta saranaprasarana pendukung pembelajaran. Secara kualitatif disparitas yang terjadi diantara ketiga jenis sekolah tersebut memiliki trend (kecenderungan) dimana peningkatan kompleksitas permasalahan terjadi secara berurutan mulai dari sekolah favorit memiliki, sekolah nonfavorit dan sekolah dalam pesantren.

Dua katagori permasalahan dalam pembelajaran IPA yang lain pada ketiga jenis sekolah tersebut relatif sama. Dua katagori tersebut adalah permasalahan mengenai komunikasi orang tua-sekolah serta kondisi kurikulum dan kebijakan. Dengan kondisi dan alasan berbeda ternyata komunikasi sekolah dan orang tua sulit untuk diwujudkan. Selain dikarenakan faktor paradigma masyarakat Sumenep yang umumnya menyerahkan tanggung jawab belajar anak sepenuhnya pada sekolah, penyebab yang lain kemungkinan besar adalah kondisi sekolah yang belum melakukan pendekatan secara optimal kepada masyarakat. Orientasi kurikulum yang masih pada kuantitas dan berbagai inkonsistensi kebijakan turut menguatkan mengapa sekolah (terutama guru) belum dapat bekerja sama dengan masyarakat untuk meningkatkan kualitas pembelajaran, khususnya IPA. Kedua jenis permasalahan inilah yang tampaknya paling berat. 
Tabel 4.1 Disparitas Permasalahan Pembelajaran IPA SMP/MTs di Kabupaten Sumenep Tahun Ajaran 2010-2011

\begin{tabular}{|c|c|c|c|}
\hline Permasalahan & Sekolah Favorit & Sekolah Nonfavorit & Sekolah dalam Pesantren \\
\hline $\begin{array}{l}\text { 1. } \begin{array}{l}\text { Kualitas } \\
\text { belajar siswa }\end{array}\end{array}$ & $\begin{array}{l}\text { Relatif baik, terutama } \\
\text { karena siswa yang } \\
\text { masuk memang } \\
\text { memiliki kualitas } \\
\text { belajar yang baik. }\end{array}$ & $\begin{array}{l}\text { Kurang baik, terutama } \\
\text { karena siswa yang masuk } \\
\text { merupakan mereka yang } \\
\text { tidak bisa masuk ke } \\
\text { sekolah favorit. }\end{array}$ & $\begin{array}{l}\text { kurang baik, terutama } \\
\text { karena niat utama siswa } \\
\text { masuk kecenderungannya } \\
\text { adalah untuk belajar } \\
\text { agama. }\end{array}$ \\
\hline $\begin{array}{l}\text { 2. Latar belakang } \\
\text { budaya dan } \\
\text { orang tua }\end{array}$ & $\begin{array}{l}\text { terutama berasal dari } \\
\text { orang-orang dengan } \\
\text { pendidikan yang cukup } \\
\text { baik. }\end{array}$ & $\begin{array}{l}\text { terutama berasal dari } \\
\text { masyarakat yang tingkat } \\
\text { pendidikan dan } \\
\text { perhatiannya terhadap } \\
\text { pembelajaran rendah. }\end{array}$ & $\begin{array}{l}\text { Berasal dari keluarga yang } \\
\text { letaknya sangat jauh dari } \\
\text { sekolah. Orientasi } \\
\text { menyekolahkan anak untuk } \\
\text { belajar agama. }\end{array}$ \\
\hline 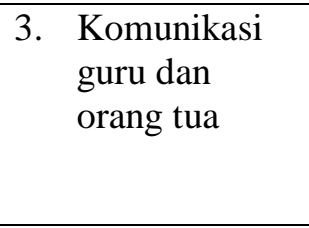 & $\begin{array}{l}\text { Sulit untuk dilakukan } \\
\text { secara rutin. Masih } \\
\text { diutamakan untuk } \\
\text { siswa yang } \\
\text { bermasalah. } \\
\end{array}$ & $\begin{array}{l}\text { Sulit untuk dilakukan } \\
\text { secara rutin. Masih } \\
\text { diutamakan untuk siswa } \\
\text { yang bermasalah. }\end{array}$ & $\begin{array}{l}\text { Sulit dilakukan terutama } \\
\text { karena letak yang sangat } \\
\text { jauh. }\end{array}$ \\
\hline 4. Kondisi guru & $\begin{array}{l}\text { Implementasi RPP } \\
\text { tidak maksimal. } \\
\text { Adanya kemalasan } \\
\text { untuk berkembang } \\
\text { pada guru senior. }\end{array}$ & $\begin{array}{l}\text { Implementasi RPP dan } \\
\text { pemilihan metode } \\
\text { mengajar tidak } \\
\text { maksimal. Adanya } \\
\text { kemalasan untuk } \\
\text { berkembang pada guru } \\
\text { senior. }\end{array}$ & $\begin{array}{l}\text { Kualifikasi guru pengajar } \\
\text { umumnya tidak sesuai } \\
\text { dengan bidang IPA. } \\
\text { Implementasi RPP dan } \\
\text { pemilihan metode } \\
\text { mengajar tidak maksimal. }\end{array}$ \\
\hline $\begin{array}{l}\text { 5. Sarana dan } \\
\text { prasarana } \\
\text { pendukung } \\
\text { pembelajaran }\end{array}$ & $\begin{array}{l}\text { Sudah cukup } \\
\text { mendukung. } \\
\text { Kekurangan terutama } \\
\text { pada media tambahan } \\
\text { seperti LCD, dan } \\
\text { buku-buku pengayaan. }\end{array}$ & $\begin{array}{l}\text { Kurang mendukung. } \\
\text { Tingkat kekurangan } \\
\text { bervariasi, mulai dari } \\
\text { yang kekurangantenaga } \\
\text { untuk manajemen } \\
\text { laboratorium hingga } \\
\text { yang sama sekali tidak } \\
\text { memiliki lab. }\end{array}$ & $\begin{array}{l}\text { Tidak mendukung. } \\
\text { Kekurangan sarana dan } \\
\text { prasarana terutama karena } \\
\text { fokus sekolah umumnya } \\
\text { lebih mengarah pada } \\
\text { program-program } \\
\text { keagamaan. }\end{array}$ \\
\hline $\begin{array}{l}\text { 6. Kurikulum } \\
\text { dan Kebijakan }\end{array}$ & $\begin{array}{l}\text { Penilaian berorientasi } \\
\text { kuantitas, intervensi } \\
\text { kepentingan politik } \\
\text { dan inkonsistensi } \\
\text { kebijakan. }\end{array}$ & $\begin{array}{l}\text { Penilaian berorientasi } \\
\text { kuantitas, intervensi } \\
\text { kepentingan politik dan } \\
\text { inkonsistensi kebijakan. }\end{array}$ & $\begin{array}{l}\text { Penilaian berorientasi } \\
\text { kuantitas, intervensi } \\
\text { kepentingan politik dan } \\
\text { inkonsistensi kebijakan. }\end{array}$ \\
\hline
\end{tabular}

\section{KESIMPULAN DAN SARAN 4.1 Kesimpulan}

Kesimpulan yang dapat dihasilkan dari penelitian ini adalah sebagai berikut: 1) permasalahan utama dalam pembelajaran IPA SMP/MTs di Kabupaten Sumenep meliputi kualitas belajar siswa, latar belakang budaya dan orang tua, komunikasi sekolah-orang tua, kondisi guru, sarana-prasarana pendukung pembelajaran dan kurikulum-kebijakan, 2) secara kualitatif disparitas yang terjadi dalam pembelajaran IPA di SMP/MTs di kabupaten Sumenep adalah semakin kompleksnya tingkat permasalahan mulai dari sekolah favorit, sekolah nonfavorit hingga sekolah dalam pesantren.

\subsection{Saran}

Berdasarkan hasil penelitian ini maka beberapa saran yang dapat peneliti berikan adalah sebagai berikut: 1) kultur (budaya) belajar siswa yang masih rendah terutama dalam pembelajaran IPA pada 
penelitian ini belum tereksplorasi secara mendalam. Dibutuhkan penelitian lebih lanjut mengenai bagaimana budaya belajar siswa dipengaruhi oleh lingkungan masyarakatnya yang tergambarkan dalam rutinitas kegiatan siswa sehari-hari. Potensi dan hambatan-hambatan kultural apa yang dihadapi oleh anak-anak Sumenep khususnya dalam belajar IPA. Dengan penelitian ini akan terbuka suatu peluang untuk mengembangkan pembelajaran IPA yang lebih sesuai dengan kultur masyarakt Sumenep, 2) disparitas permasalahan antara ketiga kelompok sekolah memberikan penekanan akan perlunya penanganan yang lebih baik kepada sekolah nonfavorit dan terutama sekolah dalam pesantren mengenai kualitas pembelajaran IPA. Namun angka disparitas ini belum nampak secara spesifik, sehingga untuk itu diperlukan penelitian-penelitian lanjutan yang bersifat kualitatif dan kuantitatif.

\section{DAFTAR PUSTAKA}

Albrow, martin. 1999. Sociology, the basic. London: Routledge Publisher.

Arikunto.Suharsimi.2006. Prosedur Penelitian, Suatu Pendekatan Praktik. Jakarta: PT Rineka Cipta.

\section{Badan Pusat Statistik Kabupaten Sumenep. 2009. Kabupaten Sumenep dalam Angka 2009. Sumenep: Badan Pusat Statistik.}

Bungin, Burhan. 2009. Penelitian Kualitatif. Jakarta: Kencana Prenada Media Group.

Departemen Pendidikan Nasional. 2009. RENSTRA MENTERI PENDIDIKAN NASIONAL TAHUN 2010-1014. Jakarta: Depdiknas.

Donovan, Suzanne \& Bransford, John. 2005. How Students Learn Science in The Classroom. Washington: National Academy of Science.

Gagne, Robert, \& Leslie, Briggs. 1979. Principles of Instuctional Design. Illinois: Scot, Forresman \& Co.

Habibi. 2010. Pembelajaran IPA 1. Sumenep: UNIJA PRESS.

Mack, Natasha. 2005. Qualitative Reasearch Methods. North Carolina: Family Health International

Morrison, Gary. 2010. Kemp Design Model. Dalam http://www.instructionaldesign.org/ models/kemp_model.html. Diakses 2 Desember 2010.

Neuman, W.L. 2007. Basic of Social Research, Qualitative and Quantitative Approach.Second Edition. Boston: Pearson Education, Inc.

Peraturan Menteri Pendidikan Nasional Nomor 22 Tahun 2003 tentang Standar Isi

Peraturan Pemerintah Nomor 19 Tahun 2005 tentang Standar Nasional Pendidikan.

Peraturan Pemerintah Nomor 74 Tahun 2008 tentang Guru.

Ritchie, Jane. \& Lewis, Jane (ed.). 2003. Qualitative Research Practice, a Guide for Social Science Students and Researchers. London: Sage Publication.

Sudjana, Nana. 2009. Dasar-dasar Proses Belajar Mengajar. Bandung: Sinar Baru Algesindo. 
Sumiati dan Asra. 2007. Metode Pembelajaran. Bandung: CV Wacana Prima.

Undang-undang Nomor 20 Tahun 2003 tentang Sistem Pendidikan Nasional.

Undang-undang Nomor 14 Tahun 2005 tentang Guru dan Dosen.

Wilson, P.L., Nola, A.C., Gunawardena, C.N. 2005.A Qualitative Analysis of Online Group Process in Two Cultural Context. The Electronic Journal of Communication.Volume 15.Dalam

http://www.cios.org/EJCPUBLIC/0 1516.HTML.Diakses 1 Desember $\underline{2010}$ 